\title{
Landscape Approaches as a Strategic Tool in the Environmental Management of Resources and Territories: Case of Aïn Dalia Dam in Northeastern Algeria
}

\author{
Djelailia Gueroui, Badouna Baha-Eddine and Fadel Djamel
}

\begin{abstract}
Our work has attracted landscape analysis as a tool for the strategic environmental assessment of the Ain Dalia water body in north-eastern Algeria. The use of the combined method which combines two approaches, one called "user" or visual, based on the assessment of the visual fields and the other called "expert", based on a quantitative method of the different sub-units that make up our site study. The results inherent in the two methods used clearly converged. It follows that the values of the quantized views are totally in line with the qualitative or visual method.
\end{abstract}

\section{Keywords}

Dam;

Landscape analysis;

Landscape scenes

Qualitative method;

Quantitative method.

\section{INTRODUCTION}

Landscape has become an essential component in the integrated management of resources and territories. Like all environmental impact studies that are part of environmental management for normative certification. Understanding the issue of the impacts of land management on the quality of landscapes requires new considerations of management and exploitation practices but also the evolution of perceptions that the population has of the territory. In order to structure the environmental management approach within the framework of a sustainable development as stipulated by the Council of Europe [1], it is imperative to have a multidisciplinary environmental management vision where each one proceeds according to methods specific to his $[2,3,4]$ It is in this context that we have set out as a goal through this work the importance of using a strategic tool that is assessment or landscape analysis of the Aïn Dalia watercourse, which is a strategic tool for the protection of the environmental and heritage qualities of the living environments. Considering the landscaped dynamics of the stretch of water of Ain Dalia on the spatiotemporal plan, we opted for the combined method which includes a visual approach adapted to the "users" and a quantitative approach considered as an "expert" method described by Damon [5]. The latter is based on descriptive and quantitative inventories that aim to categorize this dam according to those components or elements that structure it and that are likely to influence its evolution. According to Avocat [6] the combined use of both methods has its advantages and disadvantages.

\section{Characterization of The Study Site}

Before undertaking the landscape analysis of the Aïn Dalia dam, it is important to situate it beforehand in its regional eco-morphological context. Indeed, a dam is not only containment. It is a complex ecological structure using watersheds and watersheds. Our study site, represented by the Aïn Dalia water body or dam with its various basins and watersheds, constitutes an ecological network.

The dam of Ain Dalia is located on the wadi Medjerda about ten kilometers south of the city of Souk-Ahras about $80 \mathrm{Km}$ upstream of the Tunisian border it forms a long reservoir about $10 \mathrm{Km}$. The accumulated water Serves 45 million cubic meters of domestic and industrial needs in the Souk- Ahras region. The reservoir of the dam of Ain Dalia is located in the Wilaya of Souk -Ahras in the NorthEast of Algeria. It is the main source of drinking water for the city of Souk-Ahras and neighboring towns [7].

Most of the catchment area is represented by a mountain range and its foothills with ranges ranging from 450 to $900 \mathrm{~m}$. Upstream of the basin along the watersheds of some coasts are up to $1000 \mathrm{~m}$ and more cases of the djebel at an altitude of $1120 \mathrm{~m}$, that of Kelaya, $1286 \mathrm{~m}$ and finally Tebaga, $1227 \mathrm{~m}$ [8]. The valley of Wadi Medjerda has a trapezoidal geometric shape consisting of low terraces formed of 
sandbanks and rocky outcrops. On the other hand, downstream of the town of Souk - Ahras, the bed of the Medjerda takes a sinusoidal form constituted of meanders where intertwine of deposits of pebbles and gravel [9] as Fig.1.

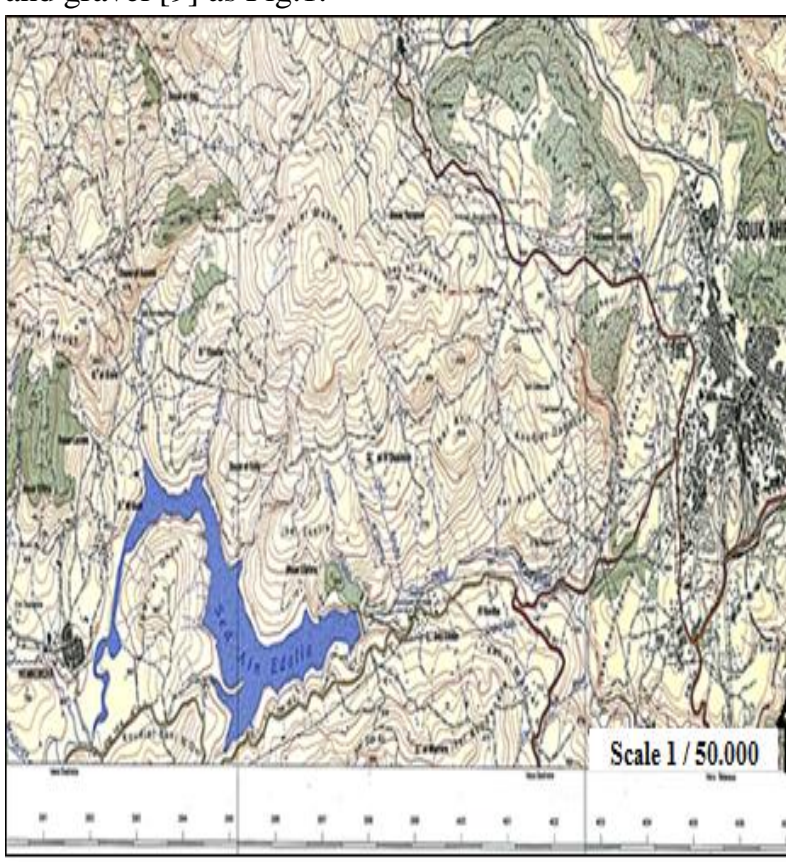

Fig. 1. Map of Souk-Ahras General Staff NJ - 32 - II - 6 EST (1997).

The Medjerda is a wadi which takes its source from Rass-El-Alia in the north-west of Souk-Ahras and then flows eastward, then plunges into the Mediterranean Sea in the "golf of Tunis". It extends over $416 \mathrm{~km}$ of which a quarter of its length is located in the Wilaya of Souk-Ahras. The total area of the Medjerda catchment area is estimated at $23,700 \mathrm{~km}^{2}$, of which $7600 \mathrm{~km}^{2}$ is in Algerian territory [10]. The hydrographic network of this part of the basin consists of the wadi of Medjerda and its main tributaries as well as very small rivers and streams (Fig.2).

Since 1985, Wadi Medjerda has been remarkable for the Ain Dalia reservoir, with a capacity of 82 million $\mathrm{m}^{3}$, still in service, which crowns an area of the catchment area equal to $193 \mathrm{~km}^{2}$ [11].

\section{STUdy METHODS}

In the late 1990s, the practice of assessing landscape qualities evolved into a combination of expert and user methods. These combined methods use the two approaches which are applied in parallel to Clay and Tress [12,13].Given the spatial dynamics of the Ain Dalia water body on the spatio-temporal plane, we opted for the so-called combined method recommended by a number of authors, which includes a visual approach adapted to the users and a quantitative approach Considered as an expert method. The latter is based on descriptive and quantitative inventories that aim to categorize this dam according to those components or elements that structure it and that are likely to influence its evolution.

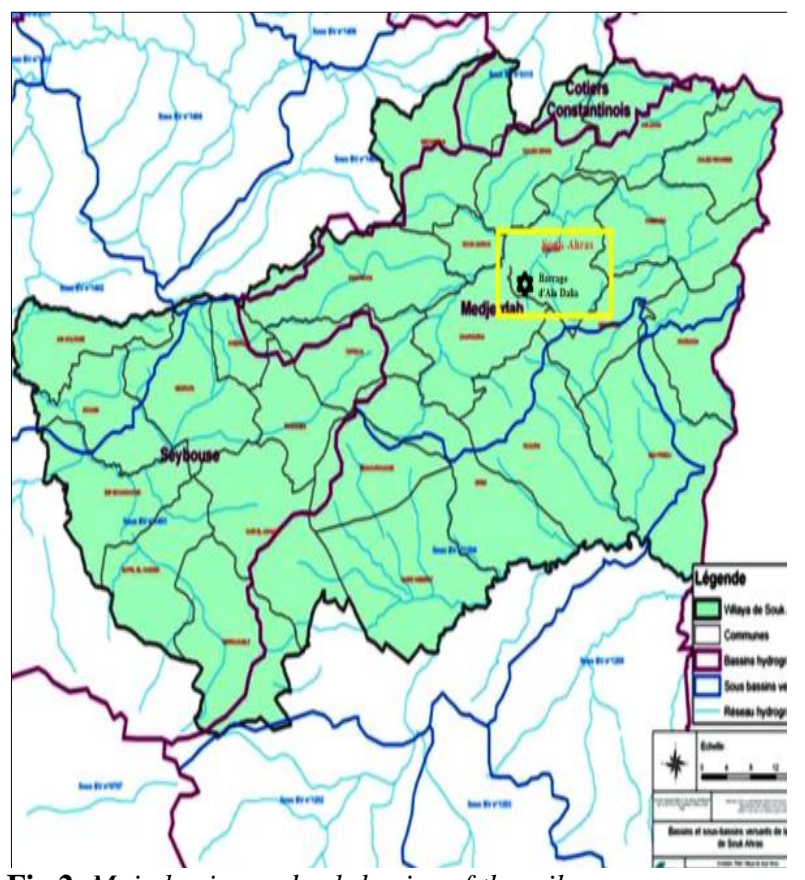

Fig 2. Main basins and sub-basins of the wilaya of Souk-Ahras.

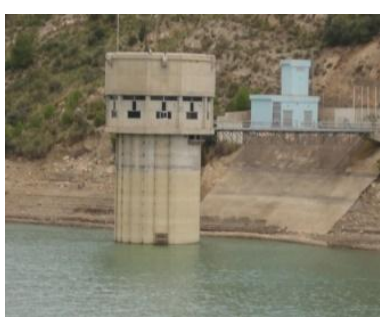

Photo 1

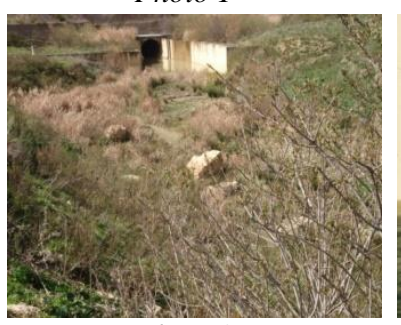

Photo 3

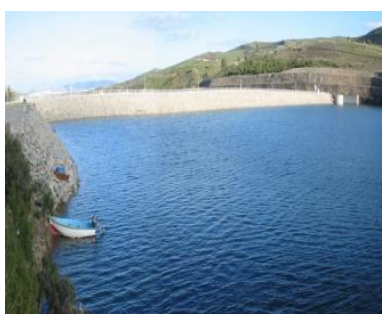

Photo 2

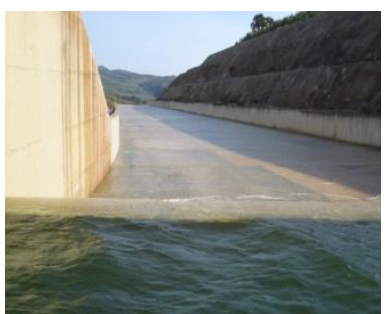

Photo 4
Photos 1 to 4. Structures of Aïn Dalia dam

\section{A- Visual Method or User Approach}

This method highlights the links between object and subject. It was used in the field of agroforestry by Liboiron, Hunziker and Franco $[14,15,16]$.

As for our approach to this method which required in three main steps:

1/ The visual study proper of the Ain Dalia dam.

2/ An inventory of the different perceptions of the lake and its surroundings 
3/ A summary of the data gathered during the first two phases in order to highlight the potential of the different landscape units of the dam and its environment.

Our method of study is based on a zoning of the area into several landscape units defined according to the following criteria:

- Topography;

- Vegetation cover;

- Habitat;

- Humanization;

- Hydrography;

- Visual quality.

This method has often been used by Fadel and Badouna $[17,18]$. To carry out this study, we took the left bank of the dam along the wilaya road connecting Souk-Ahras to Hennacha. The external observation allowed us to grasp the structuring of the water body and its various subunits. The satellite photo was necessary to bring out the landscape units of the dam. On the ground, a visual medium was needed which is represented by a camera to immortalize the visual sequences from the viewpoints.

\section{B - Expert or Quantitative Method}

This "user" evaluation remains incomplete and subjective if we do not couple it with the quantitative or "expert" method described by different authors Gaudreau \& Fadel $[19,20]$. Through this method Neuray and Fadel $[21,22]$ uses the values of views which require prior to the quotation of some parameters which are:

- Length of views (L).

- Calculating the vertical dimensions of the views (R).

- Calculation of valuation factors (S).

- Calculation of the sum of the value of the elements $(\Sigma \mathrm{e})$ quantified before or after the development proposals.

Calculating the basic parameters of the view values

\section{*Length of view $(L)$}

The length of the view is calculated according to the logarithmic function formulated below:

$$
\mathrm{L}=1 / 210 . \log 10.1
$$

With:

1: length of the view expressed in hectometer.

*Calculation of the vertical dimensions of views (R)

The vertical dimensions of the view are calculated using a formula that takes into account both the inclination of the slope in front of the viewer, the actual level of elevation, the height of the horizon and the relative dimension elements. It is represented by the formula below:

$$
\mathrm{R}=1+\sin \alpha+\sin \beta+\sin \gamma+\mathrm{d} / 100
$$

With:

$\alpha$ : angle formed by the horizontal and foreground about 30 meters;

$\beta$ : angle formed by the horizontal and a line tangent to the highest part of the foreground;

$\gamma$ : angle formed by the horizontal and a tangent line at the top of the elements located at more than 50 meters;

$\mathrm{d}$ : difference in height actually measured in meters.

\section{*Calculation of the valuation factor $(S)$}

The valuation factors are determined subjectively despite their integration into a mathematical formulation. They have an important role in the visual quality of a landscape. The main factors are:

- Presence of water.

- Presence of rocks, rocky points, sharp mountains.

- Dimension and quality of the space open to the observer.

- Presence of successive plans.

- Distribution of the elements in the landscape zone to less than 1000 meters.

- Distribution of the elements in the background to more than 1000 meters.

- Accentuation of the natural forms of relief.

- Visual quality.

- Integrity of the landscape.

They are marked positively or negatively from 1 to 10 in order to obtain the factor $\mathrm{T}$ additionally. The valuation factor is given by the formula below:

$$
\mathrm{S}=1+0, \mathrm{~T}
$$

\section{* Calculation of the base value of views}

The basic value of the view depends essentially on three factors: length of view, vertical dimension, valuation factors. The base value of the view shown in the formula below shows the product of the different factors.

$$
\mathrm{V}=\mathrm{L} \times \mathrm{R} \times \mathrm{S}
$$

With:
L: length of the view;
$\mathrm{R}$ : vertical dimensions of the view;
$\mathrm{S}$ : valuation factors;

This basic value of the view represents a situation of a landscape perceived from a point of view without taking into account the elements existing or to be introduced into this landscape during a possible development. Thus the actual value of the view ( $\left.\mathrm{V}^{\prime}\right)$ is obtained after adding the sum of the values of the elements to the base value of the view according to:

$$
\mathrm{V}^{\prime}=\mathrm{V}+(\Sigma \mathrm{e})=\mathrm{L} \times \mathrm{R} \times \mathrm{S}+(\Sigma \mathrm{e})
$$




\section{RESULTS AND DISCUSSIONS}

A. Choice of Points of View and Their Characteristics

The choice of their location and number remains subjective but necessarily requires the opening of the visual field allowing the observation of the landscape. These points of view may be located inside or outside the study site from communication routes, ridge lines, etc. Given the inaccessibility of the right bank of the dam, the viewpoints retained are all located on the left bank from a communication road which is the wilaya road connecting Souk-Ahras to Hennencha. Due to this it is very homogeneous structure, almost totally linear, the Aïn Dalia lake was easy to understand. Thus, three points of view have been imposed by themselves because of the opening of their field of view both on the site studied and on the surrounding landscape according to the altitudinal parameter of our path (Fig.3).The different characteristics of the points of view are shown in Table1.

\section{B. Application of the Visual Method or "User" Approach}

Due to its heterogeneous topography, the study site presents two large landscape units:

- A low part that is relatively homogeneous on the topographical plane. It is represented by the whole reservoir or body of water.

- A topographic part which is topographically heterogeneous, constituted by all the mountain massifs surrounding the Aïn Dalia dam (Fig.4).
It is through the description of the photographic support that we try to share the same impression with that of a profane. It should be noted that the visual field of the three points of view is open over more than $90^{\circ}$. This opening of the visual field allowed us a distant perception. Thus, the most distant elements appear in their volume, more particularly the mountain massifs.

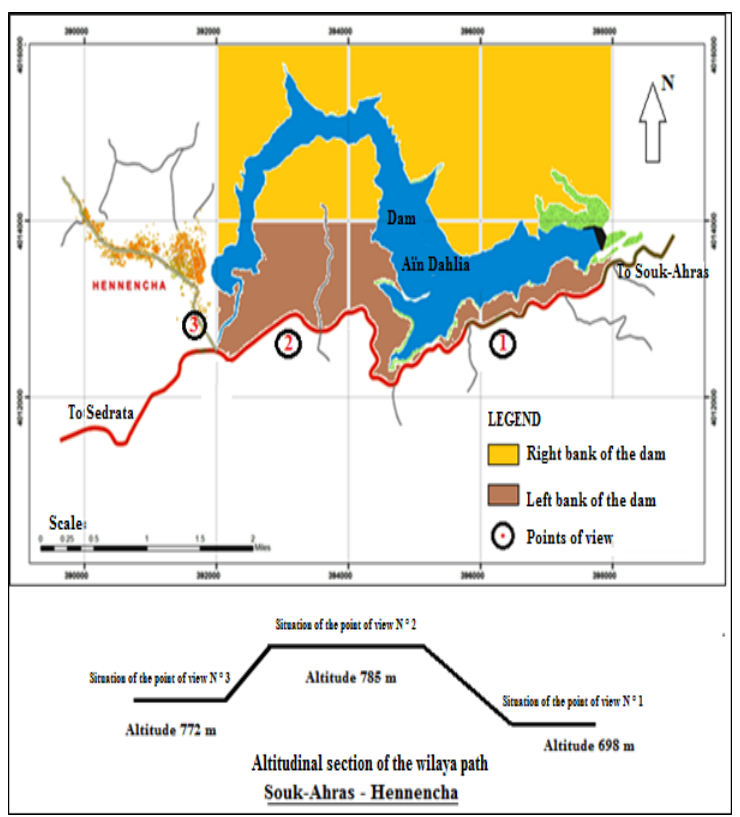

Fig 3. Situation of the views of the Aïn Dalia dam

Table1. Characteristics of the views points of the left bank of the Aïn Dalia dam

\begin{tabular}{|c|c|c|c|c|c|}
\hline \multirow{3}{*}{$\begin{array}{l}\text { Location of points } \\
\text { of view }\end{array}$} & \multicolumn{5}{|c|}{ Direction : Souk-Ahras - Hennencha } \\
\hline & \multicolumn{2}{|c|}{$\begin{array}{c}\text { Station } \mathbf{1} \\
0 \text { à } 3 \mathrm{Km} \\
\text { Lat. } 36^{\circ} 15^{\prime} 20,377^{\prime} N \\
\text { Long. } 7^{\circ} 51^{\prime} 4,70 \mathrm{E} \\
\text { Alt. } 698 \mathrm{~m}\end{array}$} & \multicolumn{2}{|c|}{$\begin{array}{c}\text { Station } \mathbf{2} \\
3 \text { à } 7 \mathrm{Km} \\
\text { Lat. } 36^{\circ} 14^{\prime} 54,54 \text { ' } N \\
\text { Long. } 7^{\circ} 49^{\prime} 28,99{ }^{\prime \prime} E \\
\text { Alt. } 785 \mathrm{~m}\end{array}$} & \multirow[t]{2}{*}{$\begin{array}{c}\text { Station 3 } \\
7 \text { à } 9,5 \mathrm{Km} \\
\text { Lat. } 36^{\circ} 15^{\prime}, 20,37 \mathrm{~N} \\
\text { Long. } 7^{\circ} 47^{\prime} 43,23^{\prime \prime} \mathrm{E} \\
\text { Alt. } 772 \mathrm{~m} \\
\text { Open }\end{array}$} \\
\hline & Open & Open & Open & Open & \\
\hline $\begin{array}{l}\text { Degree of aperture of the } \\
\text { visual field (graden) }\end{array}$ & +90 & +90 & +180 & +180 & +90 \\
\hline Direction of view & $\mathrm{N}$ & N.W & N.E & S.E & N.E \\
\hline Length of view (he) & 05 & 08 & 10 & 10 & 10 \\
\hline $\begin{array}{c}\text { Visual angle of } \\
\text { vertical dimensions } \\
\alpha\end{array}$ & 10 & 35 & 60 & 60 & 00 \\
\hline$\beta$ & 30 & 40 & 45 & 40 & 25 \\
\hline$\gamma$ & 45 & 40 & 50 & 50 & 30 \\
\hline $\begin{array}{l}\text { Made uneven perceived (D) } \\
\text { in meter }\end{array}$ & 05 & 10 & 25 & 25 & 00 \\
\hline
\end{tabular}




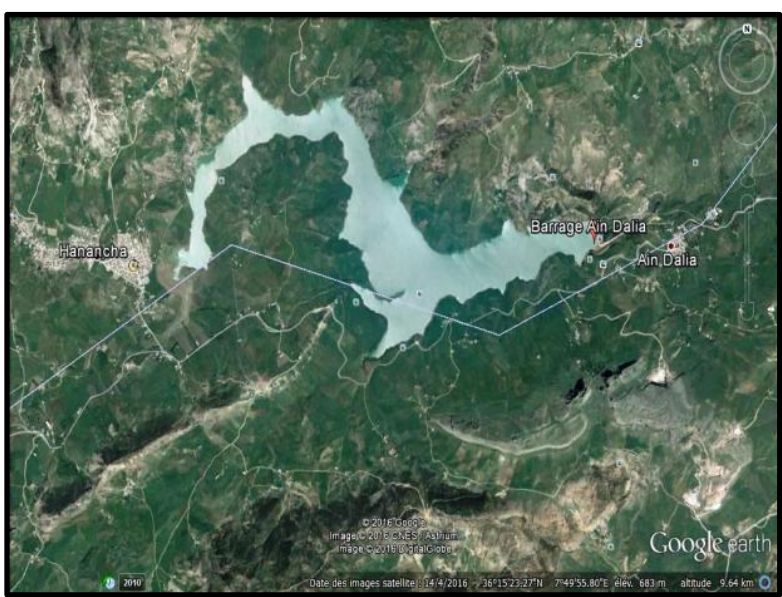

Fig 4. Satellite photo of the Aïn Dalia dam and its basins and watersheds(Google Eart 2016)

On the other hand, the closest elements are better perceived as the water body and its banks of the right bank. Only three points of view were chosen because of the relative linearity of the water body. They are representative of the three landscape sub - units that are upstream, median and downstream of the dam (Fig.5).

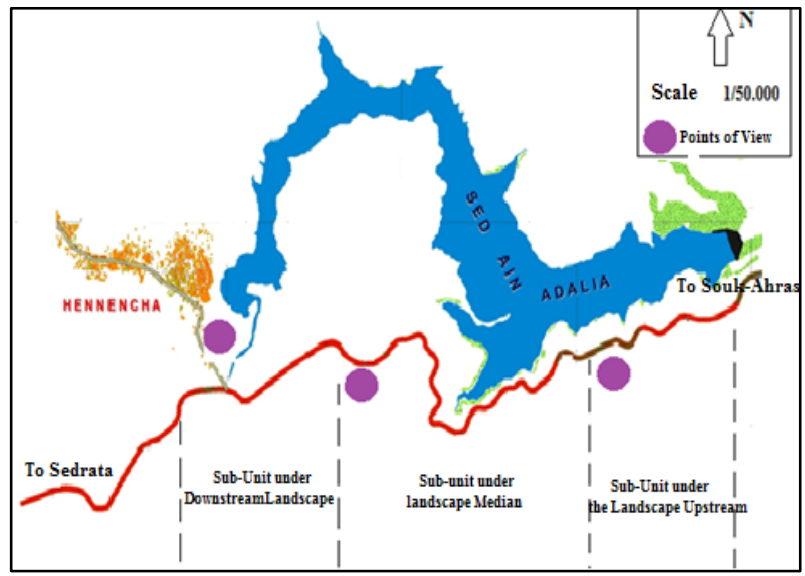

Fig 5. Views of the landscape sub-units of the Aïn Dalia dam

\section{* Visual assessment of the station1 of the dam: subunit upstream}

The visual field is practically open over more than $90^{\circ}$ in the North, North-West directions. Management perception remains limited. It is a subunit easily identifiable in the north direction due to its strongly artificialized components which includes:

- Dam or dam itself, heavy infrastructure made of concrete with the tower (Photos 5 and 6).

- Concrete spillway with the damping basin connects the watershed of Medjerda (photos 7 and 8).

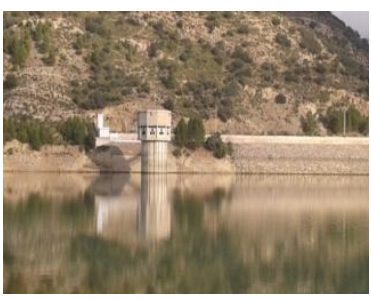

Photo 5

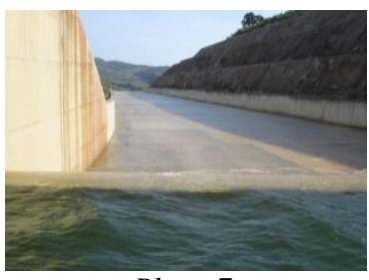

Photo 7

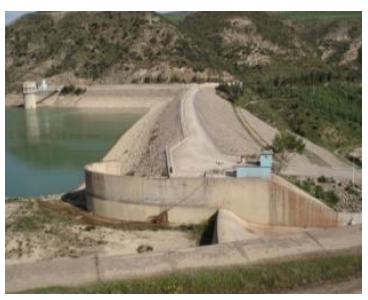

Photo 6

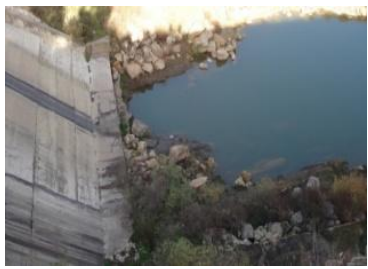

Photo 8
Photos 5 to 8. Artificial components of the upstream subunit of Aïn Dalia dam.

On the other hand, the perception of the upstream sub-unit of the dam in the north-west direction presents a much less artificial facies. The visual field is open on more than $90^{\circ}$ with a rather distant view:

- In the foreground the elements are better apprehended with a perception of detail of the shore of the left bank with introduced tree vegetation. We note an intense erosive phenomenon of the bank of the left bank with also some anthropic activity detrimental to the stabilization of the bank (Photos 9 and 10).

- The median zone remains the most perceived by its important surface. This is the water body. This is the most remarkable component of the study site (Photos 10 and 11).

- In the background, the perception is distant where the elements appear by their volume such as the mountain massifs (photos 9 to 12).

\section{*Visual assessment of the station 2 of the dam: under the median unit}

It should be noted that this viewpoint is located on the highest part from the wilaya path connecting Souk-Ahras to Sedrata. The visual field is open in the northeast and south-east directions at an angle of $180^{\circ}$.

It can be considered as the strong point of the whole site because it offers simultaneous sequential views over a large part of the territory of the water and its environment:

- A foreground, the essential component of the site, represented by the lake and its eroded banks and the agricultural fabric and plantations introduced.

- In the background, the components attached to the lake, represented by the foot-mounts, meadow (photos 13 to 16 ). 


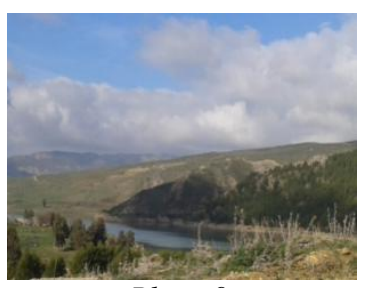

Photo 9

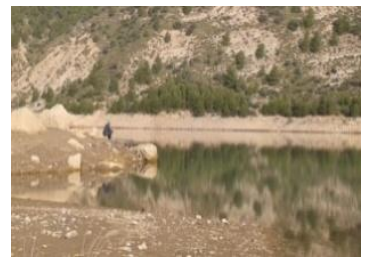

Photo 11

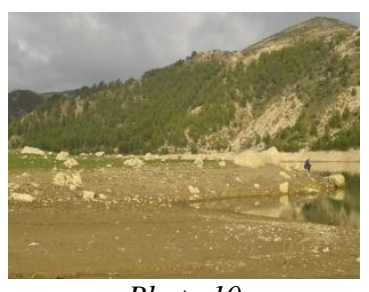

Photo 10

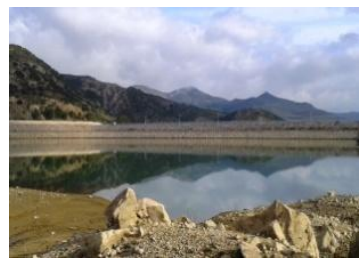

Photo 12
Photos 9 to 12. Landscape atmosphere in the north-west direction of the downstream sub-unit.

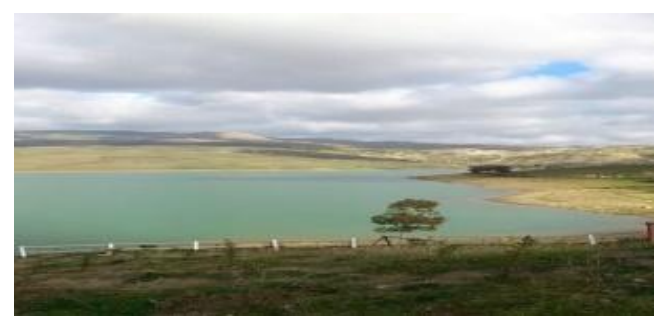

Photo 13

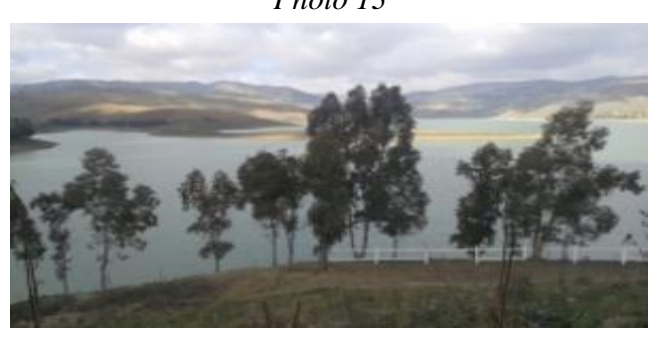

Photo 14

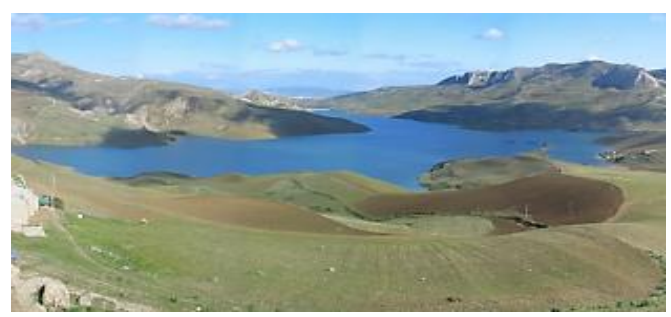

Photo 15

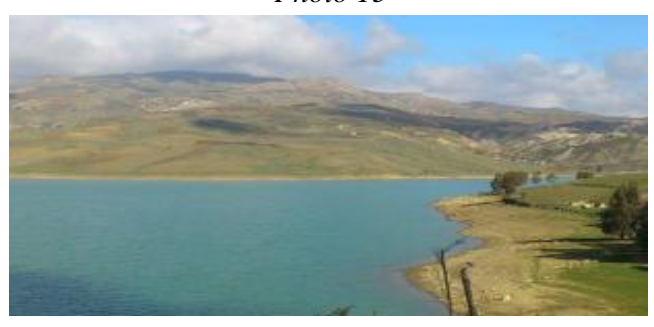

Photo 16

Photos 13 to 16. Landscape ambience of the median subunit of the Ain Dalia dam

\section{*Visual assessment of the station 3 of the dam: sub unit downstream}

The visual field of the downstream part adjacent to the village of Hennencha is more than $90^{\circ}$ north-east. It is the landscape sub-unit most opposed to the upstream part. In the foreground appear a lawn and hydrophilic vegetation. Presence of agricultural fabric is on the downstream banks of the dam. The elements of the background are perceived by their volumes such as mountain ranges. It should be emphasized that the downstream part which is close to the urban fabric of Hennencha is subjected to an incessant degradation. In fact, this sub-unit, which should be protected from all anthropogenic actions, is the object of construction which appears to be unlawful added to the various solid and liquid discharges on the banks of the lake (photos 17, 18).

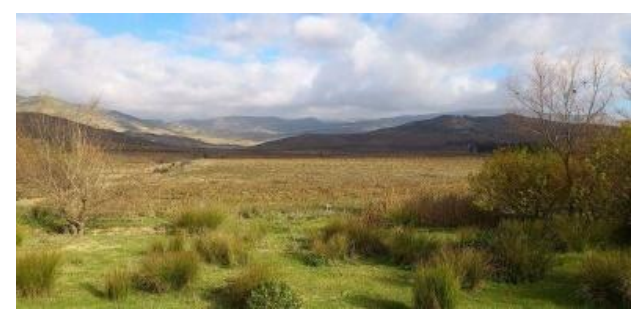

Photo 17

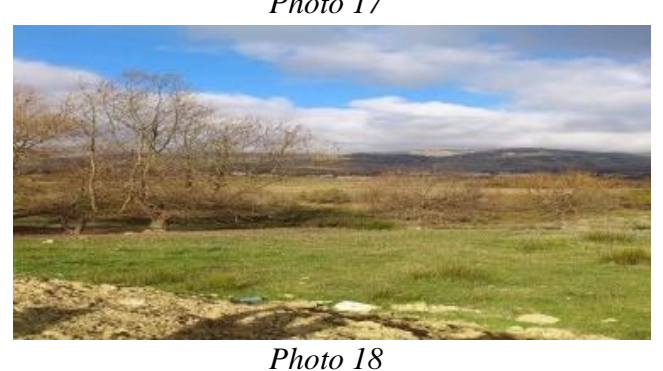

Photos 17 to 18. Landscape ambience of the median sub-unit of the Ä̈n Dalia dam

\section{Results of the quantitative method or "expert approach" $^{\prime \prime}$}

The Table 2 shows all parameter values of the three (03) stations selected from the viewpoints on the route of the wilaya path that connects SoukAhras to Sedrata. In this table with two inputs are represented the different data which fall within the formula of the base value of the views and which are:

- $\quad$ Length of the view (L).

- Vertical dimensions of views (R).

- $\quad$ Factors for the valuation of views (S).

The results of calculations of the base values of the views of the three (03) stations are recorded in Table 3. 
International Journal of Advanced Engineering and Management

Table 2. Values of parameters: current situation of the Aïn Dalia dam

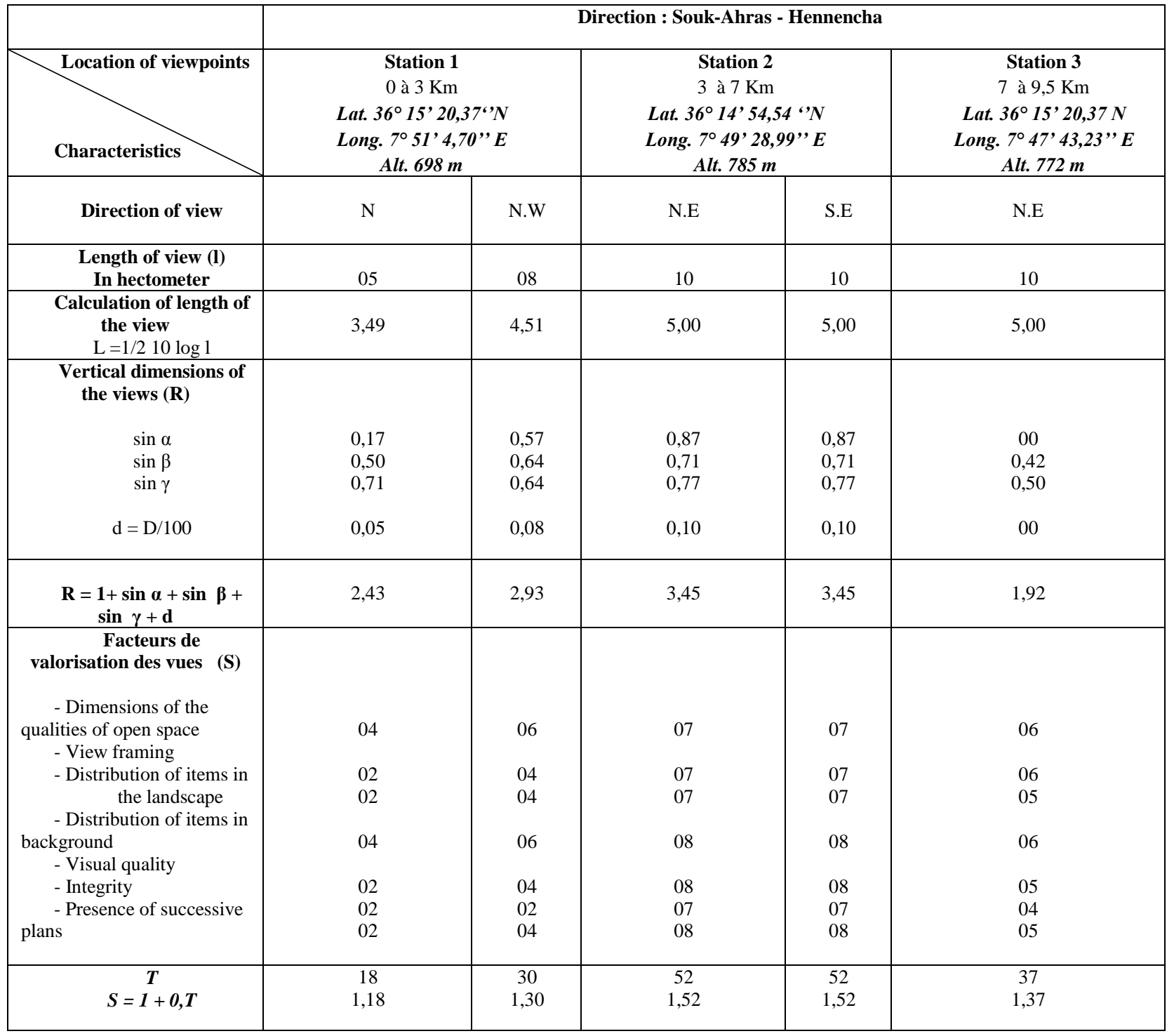

Table3. Calculation of the basic value of the views of the Aïn Dalia dam

\begin{tabular}{|c|c|c|c|c|c|}
\hline \multirow[t]{2}{*}{ Stations } & \multicolumn{2}{|c|}{$\begin{array}{l}\text { Station } 1 \\
0 \text { à } 3 \mathrm{Km} \\
\text { Lat. } 36^{\circ} 15^{\prime} 20,37^{\prime}{ }^{\prime} N \\
\text { Long. } 7^{\circ} 51^{\prime} 4,70^{\prime \prime} E \\
\text { Alt. } 698 \mathrm{~m} \\
\end{array}$} & \multicolumn{2}{|c|}{$\begin{array}{c}\text { Station } 2 \\
3 \text { à } 7 \mathrm{Km} \\
\text { Lat. } 36^{\circ} 14 ' 54,54 \text { '’ } \\
\text { Long. } 7^{\circ} 49 \text { ' } 28,99, ' E \\
\text { Alt. } 785 \mathrm{~m} \\
\end{array}$} & \multirow{2}{*}{$\begin{array}{c}\text { Station } 3 \\
7 \text { à } 9,5 \mathrm{~km} \\
\text { Lat. } 36^{\circ} 15,20,37 \mathrm{~N} \\
\text { Long. } 7^{\circ} 47^{\prime}, 43,23,{ }^{\prime} \mathrm{E} \\
\text { Alt. } 772 \mathrm{~m} \\
\text { N.E } \\
\end{array}$} \\
\hline & $\mathrm{N}$ & N.W & N.E & S.E & \\
\hline $\begin{array}{c}\text { Basic values of views } \\
\text { V }=\text { L. R .S }\end{array}$ & 10,00 & 17,18 & 26,22 & 26,22 & 13,15 \\
\hline
\end{tabular}


The Tables 2 and 3 shows that the basic values of the views of the station 2 in the two directions of the visual field are the most important with respect to those of the stations 1 and 3 . This is probably due to the value of the dimensions ( $\mathrm{R})$ which is the highest. Indeed, the viewpoint of the station 2 is at an altitude of $785 \mathrm{~m}$ and consequently increases the value of the vertical dimensions $(\mathrm{R})$. In addition, station 2 , which represents the median sub-unit of the body of water, offers greater visual quality and integrity because it is the least artificial or humanized. It has the highest value of valorization factors (S) compared to stations 1 and 3 which are more humanized (presence of dam infrastructure and proximity to the Hennencha urban area). It is also necessary to emphasize the length of the view (L) of the station 2 which is at least equal to or greater than the other two stations. If we compare the visual approach called the "user" method with the quantitative approach or the "expert" method, we find in the majority of the stations a certain similarity. The comparison of the value of the views of the three stations with that of the visual study finds a convergence in their interpretation. Nevertheless, in their application in a concerted framework, it would be preferable to refer to the "expert" approach, which uses quantitative values which are therefore less subjective than the visual approach called "user". Moreover, the so-called "expert" approach makes it possible to quantify the value of the views after any development by integrating a variable named the sum of the elements $(\Sigma \mathrm{e})$. This factor includes all new components or elements that will be integrated into the baseline value of a view that reflects the current situation of the Ain Dalia water body.

\section{CONCLUSION}

Our work on landscape analysis as a tool for the strategic environmental assessment of the Aïn Dalia water area in the wilaya of Souk-Ahras enabled us to use two approaches or methods, one called "user" "Or visual one based on the assessment of the visual fields of the dam of Aïn Dalia and the other called" expert "based on the landscape quantification of the various subunits. After quantifying the base value of the views from three viewpoints of the dam, located on the wilaya path connecting Souk-Ahras to Sedrata that we confronted it with the visual study of the same site. It appears that the results of the values of view that we have obtained are in ad equation with the visual appreciation which has made it possible to bring out the landscape potentialities from these same points of view of these three stations. We can say that the two methods have evidently converged on the landscape potential of the Ain Dalia dam. This site appeared very fragile under the various natural and anthropic constraints which are:

- Erosive phenomenon from the sub-catchment areas because the soils are less protected by a protective plant cover.

- The banks of the left bank, which are easily accessible to the population, are threatened by erosion and heavy pollution from solid and liquid discharges

- The proximity of the left bank to the road axis is a source of incessant hydrocarbon pollution linked to motor traffic.

- Ananarchic urbanization close by along the riverbanks and more particularly close to the urban fabric of Hennencha.

\section{REFERENCES}

[1] Conseil de l'Europe (2006). Paysages et développement durable". Paris, Ladocumentation française, 226p.

[2] Flatres-Mury, H. (1982). Analyse et évaluation des paysages, Revue Géographique de Lyon, 4(1), 343363.

[3] Brossard, T., Joly, D., \&Wieber, J.C. (1998). Analyse visuelle systématique des paysages de cours d'eau par deux approches complémentaires. Revue Géographique de Lyon, 73-4, 299-308.

[4] Fadel, D. (2016), Analyse paysagère comme outil dans l'aménagement du territoire. Maison d'Editions Universitaires Européennes, 124 p.

[5] Damon, G. (2004). Le paysage comme composante incontournable de la gestion intégrée des ressources et des territoires : Problématiques, enjeux et méthodes de prise en compte. Rapport préparé pour la Commission d'Étude sur la Gestion de la Forêt publique québécoise, Novembre, $183 \mathrm{p}$.

[6] Avocat, C.(1983). Lire le paysage, lire les paysages. In Actes du colloque des 24 et 25 novembre 1983, CIEREC,11-36.

[7] Direction de la Planification et de l'Aménagement du Territoire [DPAT]. (2010). Monographie de la wilaya de Souk Ahras. Direction de la Planification et de l'Aménagement du Territoire (Souk Ahras, Algérie), 86 p.

[8] Bureau National des Etudes Forestières. (1988). Etude de schéma directeur d'aménagement du bassin versant de l'oued Medjerda, Blida, 51p.

[9] Bureau National d'Etudes pour le Développement Rural. (1996). Etude d'aménagements hydroagricoles de la vallée de la Medjerda, Wilaya de Souk Ahras.Etude du Bureau National d'Etudes pour le Développement Rural.

[10] Athmani, A. (2008). Evolution de la qualité des eaux de surface cas du sous bassin versant Medjerda 
région de souk Ahras (Algérie). Mémoire de magister de l'Université Mohamed Cherif Messaidia Souk Ahras, Algérie, 166 p.

[11] Agence de bassin hydrographique. (2005). Le bassin de la Medjerda-Mellègue. Les cahiers de l'agence $n^{\circ}$ 9. Publication de l'agence de bassin hydrographique Constantinois-SeybousseMellègue, $44 \mathrm{p}$.

[12] Clay, G.R., Daniel, T.C. (2000). Scenic landscape assessment: the effects of land management jurisdiction on public perception of scenic beauty. Landscape and Urban Planning. Scenario visualization for participatory landscape planninga study,49 (12), 1-13.

[13] Tress, G., Tress, B. (2003). From Denmark.Landscape and Urban Planning, 64(3), 161-178.

[14] Liboiron, M.A., Pâquet, J. (1994). Atténuation des impacts de l'exploitation sur les paysages forestiers (partie 2). L'Aubelle, 100, 19-21.

[15] Hunziker, M.(1995).The spontaneous reforestation in abandoned agricultural lands: perception and aesthetic assessment by locals and tourists. Landscape and Urban Planning, vol. 31, 399-410.

[16] Franco, D., Mannino, F.I \&Zanetto, G. (2003). The impact of agroforestry networks on scenic beauty estimation.The role of a landscape ecological network on asocio-cultural process.Landscape and Urban Planning, vol. 62, p. 119-138.

[17] Fadel D., Donadieu P \&Kholladi M.K (2010). Estimation des potentialités paysagères d'une carrière dans le nord-est algérien en vue de son intégration dans le paysage environnant. Revue Sciences \& Technologie (D) N³2, Décembre, p. 27 - 32.

[18] Badouna B.E. \&Fadel D. (2014). Démarche paysagère des potentialités d'une carrière mercurifère dans le Nord - Est Algérien en vue de sa biorestauration en espace vert forestier. Actes du
Colloque International sur les utilisateurs des SIG GIS. Meknès, Maroc, $818-819$.

[19] Gaudreau, R., Jacobs,P \& Lalonde, G. (1986). Méthode d'analyse visuelle pour l'intégration des infrastructures de transport. Montréal, Gouvernement du Québec, Ministère des transports, Service de l'Environnement, $124 \mathrm{p}$.

[20] Fadel D.,Abdelmajid, S., Latrèche, F \&Azouz, M. (2013).Landscaped estimation of the ancientmercuriferous career potentialities in the Algeria Northeast for its bio-restoration. Al Rafidain Engineering Journal21(6), 126 - 135.

[21] Neuray, G. (1982), Des paysages pour qui ? Pourquoi ? Comment. Presses agronomiques Gembloux, 239-250.

[22] Fadel, D., Laïfa A.,Djamaï, R. \& Hadjoudja, N. (2012). Estimation the landscapedgroupings peripheral in a motorway section in the eastern Algeria by a mathematical method. Physical \& Chemical News, Vol. 65(5), 95 - 100.

Djelailia Gueroui

Department of Agronomic Sciences.

Institute Agro - Veterinary, Taoura.

University Mohamed Chérif Messaadia, Souk-Ahras, Algeria. djelailia.imane@live.fr

\section{Badouna Baha-Eddine}

Institute Agro - Veterinary, Taoura.

Laboratory of Live Science and Technology.

University Mohamed Chérif Messaadia, Souk-Ahras, Algeria

badounabaha@gmail.com

Fadel Djamel

Department of Agronomic Sciences.

Institute Agro - Veterinary, Taoura.

University Mohamed Chérif Messaadia, Souk-Ahras, Algeria.

fadeldjamel@yahoo.fr

Editor: Fadel Djamel

Editor-in-Chief: Sahadev Roy 